\title{
EDITORS' FOREWORD
}

The Armenian State Pedagogical University and the Editorial Board of WISDOM are delighted to present the $15^{\text {th }}$ issue of the journal (the second one in 2020) to the scientific community. Both the previous and present issues of WISDOM were destined to be prepared under the variety of psychological and even physical turmoil caused by COVID 19 pandemic putting our endeavours to the test. Nowadays, more than ever, as we believe, any intellectual and creative individual, in particular, grows more and more reliant on their own and other people's wisdom in order to realise, perceive, comprehend, value, and generalise, under the current circumstances, the transformations occurring within their own and other people's rationale, as well as, the activities and conduct stemming from the latter. Now we can only hope that the results of ongoing experiment-based explorations will enable the Natural Sciences to come up with the particular philosophical sensibility and interpretive prospects so that, while overcoming the unknowledgeable, the knowledge and the innovative means of gaining it could provide the humanity with shrewd behaviour together with level-headed ways of harmonious survival.

We are also pleased to inform of the two attainments that WISDOM has recently gained. First of all, having solved some technical issues, the Editorial Board and the periodical have been granted with membership within LOCKSS (The Global LOCKSS Network, see: https://www. lockss.org/join-lockss/networks/global-lockss-network) - a prominent platform that, from now on, will deposit the electronic version of our journal.

Moreover, the second accomplishment was announced on May 06, 2020: Scopus international scientometric database reckoned the Cite Score Tracker for WISDOM - 0.2 - and the journal appeared as number 406 among 606 periodicals on Arts and Humanities: Philosophy (see: https://www.scopus.com/sourceid/2110087 3483).

The 18 articles published in present issue reflect and dwell on problems traditionally addressed in various sections of the journal: Epistemology, Philosophy of Science, Metaphilosophy, Argumentation, Communication; Social and Political Philosophy; History of Philosophy, Philosophy of Art, Philosophy of Law.

The observations, achievements and positive feedback received on the already published issues of the journal are the evidence of the significance and value of the papers circulated so far.

We extend our sincerest gratitude to all the authors, reviewers, professional critics and assessors of the papers involved. We also extend our special appreciation to Armenian State Pedagogical University's Administration for its consistent support in publishing the periodical.

Given the significance of the underlying principle of pluralism over scientific issues and freedom of speech, we should remind that the authors carry primary responsibility for the viewpoints introduced in their papers which may not necessarily coincide with those of the Editorial Board. 


\section{EPISTEMOLOGY, PHILOSOPHY OF SCIENCE,}

METAPHILOSOPHY, ARGUMENTATION, COMMUNICATION 
DOI: 10.24234/wisdom.v15i2.334

Natalia FRASYNIUK, Iryna SVIDER

\title{
PATIENCE: AN INTRODUCTION TO THE CONCEPT
}

\begin{abstract}
The paper considers the definition and characteristics of concept within the main aspects of its study, in particular, epistemological, philosophical, linguo-cultural, cognitive and psycholinguistic. The experience of working out the various approaches to the interpretation and formation of the concept is reflected. Patience is one of the key concepts on which society relies, using it as a key to maintain human rights and freedoms. The genesis of patience in philosophy is related to the person's representation of the world, the formation of abstract norms of behaviour and the embodiment of this behaviour in a particular situation.

In modern cognitive linguistics, studying of the concept is rather actual and controversial nowadays, as it is functionally significant for the corresponding culture. Any concept is realized in language units. We have made the semantic-etymological analysis of the word patience and come to the conclusion that semantic structure of the concept "patience" in English consists of the different meanings, forming the conceptual layer of the investigated concept.
\end{abstract}

Keywords: concept, meaning, notion, cognition, formation, patience, virtue, mentality.

Introduction

Conceptual analysis is one of the modern comprehensive approaches in the study of social and humanities studies that enables the investigation of the concept in connection with its internal and extra-linguistic expressions. A concept is a unit of the conceptual sphere - an ordered set of mental units that includes all the mental characteristics of a phenomenon reflected in the linguistic consciousness.

As for the concept, there are seven main lines of research: the logical-philosophical (J. Kenny, C. Pearce, G. Frege), philosophical (J. Delos, F. Guattari), linguistic (V. Hack, V. Zvegintsev, O. Taranenko), linguocultural (A. Vezhbitskaya, V. Krasnyi, V. Maslov, V. Ivashchen- ko), cognitive (O. Kubryakova, Z. Popova, J. Sternin, V. Demiankov), psycholinguistic (O. Zalevskaya, O. Selivanova, L. Lysychenko, V. Starko) and literary and culturological (L. Gruzberg, L. Ivanova, O. Kaganovskaya).

\section{The Main Approaches to Concept Studying}

A definition of the concept within the framework of the philosophical theory of cognition and reflection of reality varies in the following range: from broad (complex mental formations - thoughts, knowledge, faith, reason comprehended on the basis of a broad ontological background of things that represent the surrounding world and personal experience of a hu- 
man being) to somewhat narrowed (the meanings somebody operates in the process of reduction, or interiorization, knowledge of the surrounding world, stored in the form of value - such as life, death etc.).

In fact, the philosophical tradition still treats any concept as the reduced knowledge about the world, as a component of the worldview, of the conceptual picture of the world. From the point of view of epistemology, concepts are qualified as complex mental formations, opinions expressed in words, knowledge, faith, reason, etc., and interpreted based on a broad ontological background of things, of their own experience and of the authors' perceptual background.

As a part of the reflective theory, concepts are qualified as the meanings that human beings use in the process of internalization of knowledge about the environment, that is, within the framework of comprehension of all human activity, in the form of some "quanta" of knowledge. This understanding of concepts is close to works done by R. Schank and other representatives of the Stanford School, who view concepts as a representation of "semantic notion", initially based "semantic orientation". Guided by a particular intention, the nominee selects from the concept certain characteristics that become the basis of the nomination. So, we may affirm that the nature of the concept itself; its formation in mentality is a rather controversial issue (Selivanova, 1999, p. 24).

At the present stage of linguistics, two main approaches to the interpretation of the term "concept" can be distinguished: 1) a concept as a general notion (traditional understanding); 2) a concept as a complex of culturally determined ideas about the subject (a new understanding of the term within the lingua-philosophical scientific paradigm) (Golubovska, 2004, p. 89).
The dictionary of cognitive terms provides the following definition of the concept: "Concept is a term used to explain the units of mental or psychological resources of our consciousness and the information structure that reflects the knowledge and experience of a human being"1.

In the linguistic literature, the concept is considered as a universal entity, which is formed in consciousness on the basis of direct sensual experience, direct operations of a person with objects (Z. Popova, J. Sternin), as a logical category through which culture enters the mental world of a human being (Y. Stepanov, R. Pavilenis, etc.), as the primary expressive unit of national mentality (V. Kolesov), as a concept of practical philosophy (N. Arutyunova), as a multidimensional formation (V. Karasik, S. Lyapin), as a mental unit of operational consciousness and a global mental unit, representing the object of real or ideal world and verbally stored in the memory of native speakers (O. Kubryakova, Z. Popova, J. Sternin, O. Babushkin, O. Selivanova, L. Lisichenko etc.), and as a precise expression of meaning carried out by the speakers in written and oral communication (Likhachev).

Concepts "arise as a result of the interaction of various factors, such as national tradition, folklore, religion, ideology, life experience, patterns of art, feelings and values" (Arutyunova, 1993 , p. 3) from the meaning of the word, and they objectify the result of a collision of the dictionary meaning with the personal and national human experience. The richer the cultural experience of a person is, the richer the potentials of the concept are. They (concepts) function in the context of different types of knowledge - every-

See Kubryakova, E. S., Demiankov V. Z., Pankrats Y. G., \& Luzgina L. G. (1996). Kratkiy Slovar Kognitivnykh Terminov (Short Dictionary of Cognitive Terms, in Russian). Moscow: Lomonosov State University, Faculty of Philology. 
day, artistic and scientific. In this case, the key to the semantic model of the concept lies in the following aspects: 1) the set of attributes, which testify affiliation of one or another conceptual field; 2) definitions due to the place in the system of values; 3 ) the meaning of functions in human life (Arutyunova, 1991, pp. 3-4).

The functional features of the concept are "continuity of existence, that is, the development of semantics of the word with the deployment of the internal form to the logical limit (symbol, myth); artistic imagery; preservation of semantic syncretism of root values as a semantic invariant of the whole word-building model of entering the system of ideal components of culture; the general obligation for everyone to be aware of their belonging to this culture" (Kolesov, 1992, p. 35). By entering into systemic relations of similarity, differences and hierarchy with other concepts, concepts interact, intertwine and form a holistic system - the conceptual sphere (Popova \& Sternin, 2001, p. 18).

The concept as an object of linguistic research has verbal expression, which includes etymology of words, synonyms, antonyms, typical syntactic positions, contexts for the use (semantic complexes), semantic fields, estimations, figurative associations, metaphor, phraseology and language patterns, as well as paremia, aphorism, subjective definitions (Kompantseva, 2005, p. 75 ) and seme as separate semes, statements, texts and a set of texts (Popova \& Sternin, 2001).

The representatives of the linguistic-cultural approach (D. Likhachev, Y. Stepanov, N. Arutyunov, S. Vorkachev, S. Nikitin, S. Lyapin, M. Alefirenko, V. Karasyk, G. Sliskin) interpret a concept as a certain link between man and culture; as "multidimensional semantic formation, in which value, figurative and conceptual aspects are distinguished" (Karasik, 2004, p. 109); as a complex sign of a special nature bearing an imprint of the system as a whole (Zusman, 2003, pp. 3-29); as verbalized cultural meaning - a semantic unit of the "language" of culture, which is expressed by a verbal sign (Vorkachev, 2002), etc.

Concepts are the units of culture in the mental world, which include information about the actual or possible state of things in the world (all that a person may think, know, assume about real objects). As elements of the conceptual picture of the world, concepts integrate the whole paradigm of worlds (from the perception of life and everyday life to the scientific interpretation, reflected in the concepts). Therefore the concept may be a semantic entity, which includes subjective meanings and generally accepted conventional meanings (the potential content of the cognitive object or phenomenon).

Concept, as the basic unit of the world picture, is of great importance both for the individual linguistic person and for the linguistic and cultural community, because it 1) is a verbalized smallest unit of human experience in its ideal expression with its own field structure; 2) is a basic unit of processing, storage and transference of knowledge; 3) has boundaries and specific functions; 4) is social, its associative field is determined by its pragmatics; 5) is the main link of culture (Maslova, 2004, p. 35). Concept, as a characteristic feature of culture, is identified with a myth, a custom, a ritual and is an intermediary in the cognitive-cultural space as one of the way of presenting cultural information in language units (Oparina, 1999, pp. 27-48).

But it can also be asserted that the concept belongs neither to the culture nor to the language. "Cognition receives information about culture, where it is processed, systematized. Cognition is responsible also for the choice of linguistic 
means. So, the concept is a special unit that combines culture, cognition and language, since the concept itself belongs to knowledge determined by culture and specificated in language" (Slyshkin, 2000, p. 8).

No matter what unit a concept may be (cognitive or linguistic-cultural), its structure is complex since the concept is constantly functioning, being actualized in its various parts and aspects, comes into contact with other concepts.

According to the researchers of Volgograd School of Philological Conceptualism, the concept is a three-dimensional mental formation: "The concept has three major dimensions - figurative, conceptual and evaluative. The figurative side of the concept is visual, auditory, tactical, gustatory characteristics of objects, phenomena, events, reflected in our memory; these are the relevant indications of practical knowledge. The conceptual side of the concept includes the language fixation of the concept, its designation, description, structure, definition, comparability of the characteristics of this concept with one or another series of the concepts, which sometimes do not exist in isolation, their main property is the holographic multidimensional structure in our experience system. The evaluative side of the concept is the importance of this mental formation both for the individual and team" (Slyshkin, 2004, p. 31).

\section{Correlation between Concept, Notion and Meaning}

As a complex unit, a concept is often associated or confused with a notion and meaning. The balance between a concept, notion and meaning turned out to be a disputable issue of the linguistic conceptology. In the scientific literature, there are different points of view about the relations between these entities. Concept and notion are often equated due to the meaning of the term "concept" used in medieval scholasticism by P. Abelard, who defined it as a set of notions. Besides, the definitions of the concept, as the operational unit of mental lexicon, the information about some object of reality or as an abstract notion of individual sensory features, lead to the identification of the concept and notion, with the same characteristics and functions.

Many linguists point out that "concepts are notions, correlated with the meaning of the word" and represent one level of the structure of the linguistic personality" (Karaulov, 1987, p. 37), and underline that "semantic descriptions of concepts should most fully give the comprehension of the notion that exists in the cognition of culture bearers" (Nikitina, 1991, p. 117). O. Babushkin (1996) also calls terms "concept" and "notion" synonymous, paying attention to the gradual displacement the latter one beyond scientific circulation (p. 14).

The notion, according to some researchers, is a logically constructed concept deprived of imagery. Such statements can be understood in two ways: either the notion has no sensory image (pictures) in mind, or it has not evaluative-emotional and expressive layers, in contrast to the concept. However, in our mind, we may have some notion about emotions and assessments, so the lack of imagery in all conditions is not a differential feature of the notion and concept.

Nevertheless, a concept is not a notion, and it is an "intellectual formation that replaces an uncertain number of objects of the same kind in the process of thinking" (Askoldov-Alekseev, 1997, p. 270). Any concept does not always replace real objects. It can also be a substitute for mental functions (mathematical concepts), since "not all notions can be concepts, but only the 
most complex and most important of them" (Maslova, 2004, p. 26). The difference between concept and notion lies in the fact that a concept contains the signs that are filled in certain language group with the knowledge about the object in all its relations and connections. Thus, the notion consists of generalized features of the object, the most important, essential and necessary.

Y. Stepanov (2001), considering the concept and notion being similar in their internal form, observes that in the modern world, these terms are clearly differentiated as they relate to various sciences. Notions are cogitated and used in logic and philosophy, and whereas concepts are also experienced in logics and culturology (pp. 40-41). However, we may afford that Y. Stepanov synonymizes the concept and notion, although he emphasizes that the concept is much more abundant in content and interacts with the world of culture (p. 42).

The concept is characterized by dynamics and stability, which makes the concept a flexible and universal structure (Zusman, 2003, pp. 3-6). Moreover, a notion, according to V. Demiankov, is the structure with nominal limits agreed by the people. Any concept exists beyond agreement. Notions are created in the language in order to "have a common language" to discuss the problem, and the concepts are reconstructed to a certain degree of "(un)certainty” (Demiankov, 2001, pp. 44-46).

According to V. Goldberg, the notion reflects the most general, significant, logical features of an object or phenomenon, and the concept - significant features in their systemic organization (Goldberg, 2001).

The notion is the main component of the concept, which in the knowledge of individuals, generalized and national groups accumulates different meanings (associations and interpretati- ons) under the influence of various factors of national, cultural, religious, ideological, individual experience. It is characterized by vague definition, although it has a transparent core, which provides the meaning of the notions and the interaction between them and vague periphery. Concept and notions do not have the same internal form in the language, and in science, they act as clearly delineated synonyms.

Summing up, we may define the notions as something agreed and formed by people in order to "have a common language," and concepts are independent units that are reconstructed by people with a certain degree of (un)certainty. A concept is not a notion, but the essence of notion is the essence in its forms - image, idea and symbol. The notion is related to rational understanding, and the concept is a derivative of mentality, that creatively conveys meaning.

As for the connection between concept and meaning, some linguists identify them, reducing the definition of the first to the set of semes in the semantic structure of a word. S. Vorkachev considers the concept as "cultural-marked verbalized content, presented as a set of language realizations in terms of expression, creating the corresponding vocabulary - semantic features. First of all, these are semes common to all its linguistic implementations that "reinforce" the lexical-semantic paradigm and form its conceptual or prototype basis. Secondly, these are semantic characteristics, denoted by linguocultural ethnosemantic specificity and connected with the mentality of the native speakers or with the mentality of national linguistic personality" (Vorkachev, 2004, p. 51).

We should note that the relationship between meaning and concept is complex, because in linguistics, unfortunately, there is hardly a distinct interpretation of the term "meaning". 
J. Lacoff and M. Turner explain the nature of meaning as entirely independent of the human being. They confirm that meaning depends on the objective reality, and therefore the meaning of the statement should be the corresponding reality (Turner, 1994, pp. 91-107).

J. Fauconnier considers meaning as the subject of complex cognitive operations, which can not be directly transmitted by language forms. This is a testimony to the fact that the language provides "keys" for cognitive constructs, the success of their regulation is provided by the situation and the context (Fauconnier, 1997).

Meaning is a process, or rather the set of interacting processes, through which the establishment of the correspondence between the perceived individual word form, the socially recognized meaning of the word and the awareness of processing perceptive, cognitive and spectacular experience, somehow connected with the word, the designated object, and with the current situation in which this object is included. Furthermore, concepts as elements of knowledge are completely independent of the language, because "the concept exists not for the word itself, but for each basic (vocabulary) meaning of the word separately" (Likhachev, 1993, p. 4). So, people comprehend words at the level of their transmitted meanings, namely concepts. According to opposite views, the concept and meaning are units of different status: meaning is a linguistic essence, and the concept is a psychological one. Z. Popova and J. Sternin emphasize: "Concept is a unit of the concept sphere, the meaning is the unit of the semantic system, the semantic space of the language. The meaning through its systemic semes conveys certain features that form the concept, but it is only a part of the semantic content of the concept" (Popova \& Sternin, 2001, p. 59).
Meaning is not an independent unit, which is a thought-coded information structure in natural languages and exists in the linguistic consciousness. The meaning of the word is realized through its inclusion into the concept since the language semantics (the meaning of the word) is the part of the semantics of the concept. The meaning of the word is a concept, and concepts, being units of human mentality, represented in a particular mental act, are opposed to lexical notions and meanings.

In this research, we are mainly interested in the concept "patience" within the main aspects of its study, in particular, philosophical, linguocultural and cognitive.

\section{Philosophy of Patience}

In European philosophical literature, the concept "patience" was examined due to four dominant contexts: 1) patience is an attribute of the material and the ideal world (Aristotle); 2) patience is a virtue that is correlated with suffering and pleasure (Aristotle, Tertullian, etc.); 3) patience - "the subjective need for suffering" (Kant); 4) patience - the basis of human life and the foundation of the existence of society (Schopenhauer).

The genesis of patience in philosophy is related to the processes of development of a person's representation of the world, the formation of abstract norms of behaviour and the embodiment of this behaviour in a particular situation. Philosophy tried to penetrate the nature of patience and explain its meaning. The first attempts to describe patience as a valuable quality belong to Socrates. The philosopher, analyzing such moral qualities of a human being as good and evil, advantage and happiness, attached great importance to patience, since, to his mind, pa- 
tience was a means of "restraint", "an opportunity to tolerate", because "incontinence allows to endure neither famine nor thirst... or sleepless nights" (Xenophon, 1993, p. 140). Socrates believed that a person who can tolerate could achieve high goals in life.

According to Aristotle, patience is a state of mind that occurs in the process of upbringing and learning. Analyzing patience as a person's quality, Aristotle considers it to be good and worthy of praise and underlines that patience is one of the fundamental virtues of a person, which appears when the mind acts together with feelings. Every virtue needs practice and, therefore, to have patience, you need to constantly endure something in this life, to have moral stability and strong-willed emotional confidence.

Plato, in his studying the virtues whose knowledge is fundamental to human life, as virtue is a gift of God that a person receives regardless of the content of his knowledge, also calls patience as one of the basic virtues of human being and characterizes it as "true courage, true valour" and asserts calmness, patience and good humour to be given the top priority ${ }^{2}$.

Philosophy distinguishes corporal (physical) and moral patience. According to Aristotle, physical patience is a process a person can overcome amenities and suffering. All amenities the philosopher divides into "necessary" and "unnecessary". "Necessary" are things a person can not live without food, sleep, other physical needs. Moreover, people work a lot to get "unnecessary" ones, but they can do without them: wealth, respect, victory, etc. Emphasizing moral suffer-

2 See more in detail The Works of Plato Abridg'd: with an Account of His Life, Philosophy, Morals and Politicks.Volume 2. Retrieved December 3, 2019 from: https://books.google.com.ua/books?id=PQRjWH2Kqx UC\&pg=PA210\&dq $=$ plato + about + patience\&hl $=$ uk\&s

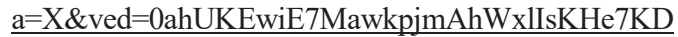
$\underline{\text { SYQ6AEIPTACH } \mathrm{v}=\text { onepage } \& \mathrm{q}=\text { patience } \& \mathrm{f}=\text { false. }}$ ings, the philosopher believed that all existing objects that come into contact with the surrounding world, or those that are experiencing internal actions, are endowed with patience. Moral patience is the ability to endure misery and pleasure.

Plato under physical patience understands the ability to experience and overcome corporal needs. Moral patience, in his opinion, is the ability to withstand the feelings caused by suffering, "endure injustice". It is interesting to note that physical patience is inherent not only to man but also to animals, to any living beings. However, it should be noted that these two kinds of patience are strictly interconnected, have one basis and interact with each other. However, moral patience will always dominate the physical one.

Human patience is caused by a subjective factor and is perceived through the conceptual level, because of the moral and ideological purpose - "a person endures for something good" (Aristotle, 2002, p. 154). Furthermore, a person will always endure to prove himself as a person in society while "his soul has been cleansed and strained from the less pleasure, and abstinence and patience have been chosen with his (whole) soul”'3.

Patience submits to the mind: "Everything that the soul tends to endure and what it endures, it ends happily, if it is directed by the mind" (Plato, 1990 p. 599). Nevertheless, at the same time patience can also form feelings. Such patience is spontaneous, and it helps a person to quickly change his attitude to what is happening in his life. For example, having lost one of his relatives,

3 See more The Works of Plato. Vol. VI. Retrieved December 3, 2019 from: https://books.google. com.ua books?id=xNJDAQAAMAAJ\&pg=PA451\&dq=patie nce + plato\&hl $=$ uk\&sa $=$ X\&ved $=0$ ahUKEwiDh5aVl5j mAhVCw4sKHdZmBxwQ6wEISzAD\#v=onepage \& $\mathrm{q}=$ patience $\& \mathrm{f}=$ false. 
a person redefines his place in this world, changes values, principles of his life.

Patience is so necessary on the path to God's affairs that no one can fulfil any commandment, any work without patience. Emphasizing the high value of patience, Tertullian notes that no living being can live without patience, because through patience, the path to salvation opens. In this case, patience becomes the form of love, which is the greatest mystery of faith. Love will survive, it will endure, because it is generous, and everything else will disappear: both languages and science and prophecy as well. Besides, underlining the importance of patience, Tertullian proves that "one does not easily attain the good health of faith and the soundness of the discipline of the Lord unless patience lends assistance thereto", 4 .

Patience takes a special place in human life, especially in religious people's life. Since it can strengthen faith, promote love, teach humility, lead to confession, control our body, harden the spirit, hold down the desire and temptation, entrust the God to rule the people's lives.

Matthew Pianalto asserts that here the active dimension of patience is obvious - the withholding of anger, punishment or judgement in forbearance, the constancy and the effort of the person who perseveres in a task. Even enduring, even waiting, require their share of mental effort. Patience is active, though in ways that may often be hidden (Pianalto, 2016, pp. 13-14).

Margaret Whipp underlined the importance of waiting in the concept of patience. In classic Christian theology, people were apt to wait patiently, being confident in God and His indulgence. Nowadays, "our go-getting society re-

\footnotetext{
4 More information see in Tertullian's letter on $\mathrm{Pa}$ tience. Retrieved December 3, 2019 from: http://www. pseudepigrapha.com/LostBooks/tertullian patience.htm.
}

gards waiting as undesirable, unwelcome and unprofitable... Occasions of unnecessary, or unexpected, waiting to provoke such discomfort and outrage in our generation... Practice and patience go together. It takes practice to become patient..." (Whipp, 2017, p. 20).

\section{Linguocultural Aspects of Patience}

Having analyzed the English dictionaries (Webster's Encyclopedic Unabridged Dictionary of the English Language, Longman Active Learning Dictionary, Collins English Dictionary, Longman Dictionary of Contemporary English, Cambridge International Dictionary of English, Oxford English Dictionary etc.), we found out that semantic structure of the concept "patience" in English consists of the different meanings, forming the conceptual layer of the investigated concept.

As we see, patience - 1) the ability to continue to wait or doing something for a long time without becoming angry or anxious; 2) the ability to accept trouble and other people's annoying behaviour without complaining or becoming angry ${ }^{5}$.

Patience - the ability to wait, or continue doing something despite difficulties, or suffering without complaining or becoming annoyed ${ }^{6}$.

Let us consider some more definitions of patience: a. The calm endurance of pain, trouble, inconvenience, etc. Formerly also foil, by the pain etc. b. Forbearance under provocation, esp. tolerance of the faults or limitations of other people, c. (The capacity for) calm, self-possessed

\footnotetext{
See: Longman Dictionary of Gontemporary English (https://www.ldoceonline.com/dictionary/patience).

6 See: Cambridge Dictionary (https://dictionary.cambridge.org/dictionary/english/patience).
} 
waiting, d. Constancy in exertion or effort; perseverance ${ }^{7}$.

Having analyzed the following vocabulary definitions, we can distinguish such features: 1) expectation; 2) endurance; 3) obedience; 4) misery; 5) self-control; 6) exposure; 7) leniency; 8) perseverance.

It should be noted that the concept "patience" in English is polysemantic, which leads to the use of it in different expressions: to try smb's patience, to exasperate smb. I have no patience with him; to lose patience; to show patience; to be patient, to have patience, to arm oneself with patience; to exasperate somebody; patience is wearing thin; patience gave way, he lost his patience, I hadn't the patience, my patience gave out; patience of Job, angelic patience; patience on a monument.

Having examined the synonymic rows of the concept "patience" and thematically related words, we distinguish the following characteristics: 1) great patience, 2) obedience, 3) expectation, 4) self-control, 5) religious virtue, 6) misery, 7) endurance, 8) perseverance, 9) leniency.

While analyzing the linguistic material (verb conjugations), we conclude that the content component of the concept "patience" is represented as follows:

1) to consistently overcome difficulties without complaints: to bear losses, to sustain losses, to suffer defeat, to suffer change, to bear hunger (cold), to endure cold (hunger), to suffer from want;

2) to resist moral suffering: to bear insolence, to bear insults, to bear the humiliation;

3) to accept the presence of something, someone: to bear one's cross, to bear wit, to suffer somebody in some manner, to bear coals, to stand one's chance, to submit to

\footnotetext{
7 See: https://www.dictionary.com/browse/patience.
}

one's destiny, to put up with smb's temper, to put up with one another;

4) to be lenient to someone, something: bear and forbear;

5) to wait for a long time without complaints: there is no hurry, there is plenty of time;

6) to endure: to put up with hardships, to be a martyr, to suffer hell;

7) to be impatient: to stand no nonsense from one, I won't put up with, I can't put up with this noise any longer, no other man would put up with you for a mother-in-law, I can't stand a good deal, but I won't have insolence, I can't stand smb./smth.for some time, I don't have to stand for his insolence, time is pressing, time is getting short, there is no time to be lost, the business is urgent/ pressing, the matter brooks no delay, the matter permits of delay, he is eager to go there, he is impatient to go there.

\section{Cognitive Contexts of Patience}

Exploring the discursive functioning of the concept "patience" in the virtual space of the Internet shows that patience is considered to be a vital quality. We deal with consciousness-based virtue of patience, in particular with regard to the British.

Anglo-Saxons believe that patience is 1) wisdom: But the only wisdom was patience; 2) virtue: Patience is a virtue darling, you'll soon go up; 3) courage: In the meantime, it seems patience remains courage.

We come across a new interpretation of patience in the consciousness of English people. They believe that patience is 1) a gift: Those who feel that patience, trust and ability to put up with uncertainty are gifts rather than skills - and gifts which not all adults share; 2) a need: Patience, 
that was the need; 3) an inspiration: The patience, care and steady hand of Charles was an inspiration, and all were impressed by his results; 4) a wealth: Her wealth was her patience; 5) a calling of Christians: Patience, which is born out of tolerance and mutual respect, while still remaining firm in belief, is still the calling of the Christian.

In the collective consciousness of the British, there is the thought that patience is needed: 1) to survive the difficult times: Patience, mon vieux, she told herself, the lady had a hard time; 2) to survive in the modern world: The flow, the flow, the drifting balance of modern life requires a certain kind of patience; 3 ) to build a business: It takes a lot of patience to build a new technology business; 4) to explain something: "The chalets are kept for group bookings" Lucy explained with so much patience as she could muster; 5) to solve the problem: The problem can only be solved with patience; 6) to create: It takes time, patience and ingenuity to create effective miniature pictures from pressed flowers, making it a fascinating part of the craft for some people; 7) to be good parents: Stimulation from parents enhances the speed of learning, and great patience is required to perceive and decode the communicating done by babies and children, both verbally and non-verbally; 8) to succeed: Patience is a necessary asset for successful training. Successful sales to Japan requires patience and sensitivity to customs; 9) to hunt: A trap was made near the entrance, and after three months of patience, she was finally caught; 10) to find a beloved woman: Lucy said, "In that case all you need is patience, and one day the right woman will come to you from out of the blue"; 11) to win the heart of a beloved woman: A wealthy bullion dealer who patiently courted an out-of-work actress for five years... was cleared yesterday of molesting her; 12) to help the sick: I would like a new member of staff to know they are there to help people who can not help themselves and they also have one hell of a lot of patience!; 13) to work efficiently: Mary was a stickler for accuracy, which is really needed in this job; you also need a lot of patience to tackle it effectively; 14) to simplify the dispute: A little courtesy, tolerance and patience will help to ease the strife, a spokesman said; 15) to modernize: Modernization at the local level was also a matter of patience; 16) to make furniture: "I have always been interested in woodwork but don't have the artistic skills or patience to make fine furniture," he said; 17) to change the world: Five minutes of your time and patience could alter - oh, the universe - for me!; 18) to teach: Sid patiently tutored me by fits and starts and assured me that technically the climb was easy, so I would cope.

Very often, with patience the British: 1) wait: I'll wait with patience till another Day; 2) listen: Time was suspended and the police heard my life story at least twice with patience; 3) agree: There were signs of inequalities and economic problems that people had to accept with patience; 4) receive: "My lord, I thought, to give you what you wanted, and what you will never get by patience," he protested defensively, but with resentment thick in his voice; 5) create: With the patience and advice from my local vet we set up a recovery programme; 6) learn: These important studies, made at night with great patience; 7) play: She starts to realize that he is bound to win, he is playing her in with an eternity of patience, amused and confident; 8) produce: Although the drawing tools are limited to freehand pixel editing, lines and fills, with patience you can produce any symbol that you require; 9) answer: So that when his mouth closed on hers she reacted passionately, and a great wave of 
love and affection for him, and for his patience, engulfed her, and carried her away; 10) say: Instead, she said quietly, and with more patience than she felt; 11) reach the highest level: Only with patience, persistence and a willingness to approach the highest levels.

Patience as vitally important virtue, receives high positive evaluation and acquires the corresponding value status in the collective consciousness of the English people. The allegations analyzed show that patience can be: 1) essential: Patience was essential; 2) parental: Mrs. Finni's parental patience finally snapped this summer; 3) little: She had a little patience but she tried; 4) strong: I'm sure, much rather have Patience Strong than Christopher Logue on his books; 5) immense: Immense patience... ... I mean, he said with exaggerated patience; 6) superhuman: $\mathrm{He}$ negotiated Chelmsford with impeccable traffic discipline and superhuman patience; 7) unlimited: Marie, their high-spirited young nanny, had endless patience with the timid child; 8) ruthless: But the history of his life so far shows (and he freely admits it) that the old John Barleycorn lies in wait for him with implacable patience; 9) important: Patience is important in our life; 10) that gives life: It is patience that has kept Lennie alive so long; 11) eternal: He was shadowy and had no face, and his patience was forever; 12) holy: She was going to use the sainted patience, the one he found most difficult to handle; 13) tired but good: Come on, baby, says Sadat, managing to convey a weary but still kindly patience; 14) reasonable: If you contain yourself in reasonable patience, and permit me to do what I came here to do, we will all be better off.

Among the statements, there are also occasional negative claims: e.g. unrelenting patience - When he turned back to drape the garments alongside his cloak and saw that Isabel was still clothed and beginning to shiver visibly with cold, his precarious patience snapped.

However, whatever patience is, it has its limits: But he added that patience had limits and he could wait a few days or two weeks. Furthermore, worst of all, it can end: We just ran out of patience with him; become exhausted: "You are a fool," Kirov spat, his patience suddenly exhausted; or lost: He finally lost both patience and nervous and became the fourth player in the match; run out: He was at the end of his patience when a message came from Merymose. That's why we have to keep patience: She could hardly keep her patience if the train was delayed and she arrived late.

It is believed that the English do not have patience: Unfortunately, as Rowell mentioned later, the Englishmen lacked a little in patience. Therefore they call for patience: More patience, less nerves.

The British themselves ask for patience: Give me patience, Give me a little more patience, because it is fast approaching to the end. After all, they are convinced that the one who has patience has faith: Faith wouldn't be, if there were no patience with it.

The English people believe that patience should be sought after: If you are not blessed with the patience of a particularly well-disposed saint, look elsewhere. And if they have found it, they want it to last long: Blanche wanted her patience to be long, but she shrugged stoically. But being patient is not easy, and therefore one who has patience must receive a reward: Every patience must be rewarded.

People thank God for patience: Thanks for your patience. I am very grateful to the minister for his patience. And therefore they are urged to obtain patience: "You take patience, Delia, I beg you to take patience", they wish patience: "Have 
patience! Patience, patience, patience," exhorted Arafat this week. Or they advise learning patience: "The old nanny thinks that it's good for her wives to learn patience in the depths of her heart". Besides patience is not for everyone, but only for the teacher: I am deeply grateful to the Technique and to my teacher for the patience that he had; judge: On the Chancery side, the main qualifications are, I think, patience and thoroughness; the gardener: Optimism and patience are the basic requisites of the city gardener; and those who suffer: Our God, we commend to Your loving care all who suffers; grant them patience.

To better comprehend the Anglo-Saxon's understanding of patience, we also have taken into account the use of the combinations of the word patience and other words. Such compounds can be synonymic and antonymic and better reveal the content of the concept "Patience".

Based on the material, patience is closely linked to 1) endurance, which is one of the components of patience; 2) perseverance and desire to achieve the goal; 3) tolerance; 4) care; 5) time; 6) accuracy; 7) understanding; 8) practice.

There are set expressions in English, such as with time and patience, with practice and patience, which are often used in the speech of the people and indicates the importance of patience in the lives of the English.

Sometimes patience is negatively assessed and regarded as a vice: My worst fault is patience and a curse: Patience is the curse of our day and age in the consciousness of the English. After all, because of impatience, some accidents may happen: Many accidents happen through impatience; people lose control of themselves: But Wapnick has become over-eager, and his impatience triggered the series of errors that led him downfall.
Interesting is the fact that often patience gives the lead to impatience. The words impatience, impatiently are popular in the language of the English people. They impatiently 1) shrug: George shrugged impatiently; 2) ask: "Well?" asked Bragg impatiently; 3) interrupt the conversation: "Yes, yes," interrupted Pumfrey impatiently; 4) look around: Maggie muttered, looking around impatiently; 5) wait: Before the fire in the sitting room, she waited impatiently for Thomas and his approval.

However, impatience can be considered a positive feature. It is desirable to have impatience that signals about love: I am looking forward to seeing you on Tuesday with the usual impatience, but Friday may be more convenient. Sometimes impatience shows a desire to work: Aren't there times when a little purposeful impatience to do this work needs to be shown.

\section{Conclusions}

Thus, the analysis of denotative lexemes objectively reveals their nature and assist distinguishing the main vectors of Anglo-Saxon's comprehension of the concept "patience":

1) persistently do something to achieve the goal, to succeed;

2) consistently without complaining bear physical suffering;

3) sustainably without complaining love and enduring family life;

4) leniently treat someone, something;

5) control yourself;

6) look forward to the best;

7) teach and bring up children to be good parents;

8) create;

9) solve problems;

10) bear the presence of something, someone; 
11) build a business;

12) change the world.

Having studied the linguistic material, we conclude that the concept "patience" is widely represented in English linguistic culture and we distinguish the following basic features of the concept "patience", which form its core: 1) expectations; 2) endurance; 3) obedience; 4) misery; 5) self-control; 6) exposure; 7) indulgence; 8) perseverance.

And the core of this concept, as we see it on the basis of investigating dictionary entries comprising verbal lexemes of the word patience in lexicographic English sources, can be represented as follows: to endure physical suffering without complaints; to withstand moral suffering; to stand the presence of something, someone; to bear someone, something; to wait for a long time without complaining; to put up with.

\section{REFERENCES}

Aristotle (2002). Metafizika. Perevod. Kommentarii. Tolkovaniya (Metaphysics. Translation. Commentary. Interpretation, in Russian). St. Petersburg: Aleteyya. Kiev: Elgar.

Arutyunova, N. D. (1991). Istina: fon i konnotaci (Verity: Context and Connotation, in Russian). In Logical Analysis of Language. Cultural Concepts (pp. 21-31). Moscow: Nauka.

Arutyunova, N. D. (1993). Vvedenie (Introduction, in Russian). In Logical Analysis of Language. Mental Actions (pp. 3-7). Moscow: Nauka.

Askoldov-Alekseev, S. A. (1997). Kontsept i slovo (Concept and Word, in Russian). In Russion Literature. From the Theory of Literature to the Structure of the Text.
Anthology (pp. 267-280). Moscow: Academy.

Babushkin, A. P. (1996). Tipy kontseptov v leksiko-frazeologicheskoi semantike yazyka (Types of Concepts in Lexical and Phraseological Semantics, in Russian). Voronezh: Voronezh National University Publication.

Demiankov, V. Z. (2001). Ponyatiye kontsept v khudozhestvennoy literature $i v$ nauchnom yazyke (Definition of Concept in Fiction and in Science, in Russian). Issues of Philology, 1, 35-47.

Fauconnier, G. (1997). Mapping in Thought and Language. Cambridge: Cambridge University Press.

Goldberg, V. B. (2001). Strukturnye svyazi v leksiko-frazeologicheskom pole (Structural Connections in Lexical and Phraseological Field, in Russian). In N. N. Boldyrev (Ed.), Language as Functional System (pp. 57-62). Tambov: Tambov University Publication.

Golubovska, I. O. (2004). Etnichni osoblivosti movnikh kartin svitu (Ethnical Characteristics of Language Picture of the World, in Ukrainian). Kyiv: Logos.

Karasik, V. I. (2004). Yazykovoi krug: lichnost', kontsepty, diskurs (Linguistic Background: Personality, Concepts, Discourse, in Russian). Moscow: Gnozis.

Karaulov, Y. N. (1987). Russkii yazyk i yazykovaya lichnost' (Russian Language and Linguistic Personality, in Russian). Moscow: Nauka.

Kolesov, V. V. (1992). Kontsept kultury: obrazponyatiye - simvol (The Concept of Culture: Image - Notion - Symbol, in Russian). Journal of St. Petersburg National University. Series 2: "Linguis 
tics", 3(16), 30-40.

Kompantseva, L. F. (2005). Kontsept i kontseptualnyi analiz: analitychna palitra (Concept and Conceptual Analysis: Analytical Palette, in Ukrainian). Studies of Luhansk National Pedagogical University, 6, 68-99.

Likhachev, D. S. (1993). Kontseptosfera russkogo yazyka (Sphere of Concepts in Russian Language, in Russian). Proceedings of the Russian Academy of Sciences. Literature and Language, 52(1), 3-9.

Maslova, V. A. (2004). Kognitivnaya lingvistika (Cognitive Linguistics, in Russian). Minsk: Tetra Systems.

Nikitina, S. E. (1991). O kontseptual'nom analize v narodnoi kulture (About Conceptual Analysis in National Culture, in Russian). In N. D. Arutyunova (Ed.), Logical Analysis of Language. Cultural Concepts (pp. 117-123). Moscow: Nauka.

Oparina, E. O. (1999) Lingvokul'turologiya: metodologicheskie osnovaniya i bazovye ponyatiya (Linguistic Cultural Studies: Methodological Background and Basic Notions, in Russian). In E. O. Oparina (Ed.), Language and Culture: A Collection of Reviews (pp. 27-48). Moscow: INION RAN.

Pianalto, M. (2016). On Patience: Reclaiming a Foundational Virtue. Lanham: Boulder, New-York, London: Lexington Books.

Plato, (1990). Menon (Meno, in Russian). In Plato's Collection Works. Volume 1. Moscow: Mysl'.

Popova, Z. D., \& Sternin, I. A. (2001). Ocherki po kognitivnoi lingvistike (Essays on Cognitive Linguistics, in Russian). Vo- ronezh: Istoki.

Selivanova, O. O. (1999). Aktualni napryamki suchasnoyi lingvistiki (Relevant Areas of Modern Linguistics, in Ukrainian). Cherkasi: Ukrainian Phytosociological Center Publishing House.

Slyshkin, G. G. (2000). Ot teksta k simvolu: lingvokul'turnye kontsepty pretsedentnykh tekstov $v$ soznaniye $i$ diskurse (From Text to Symbol: Linguocultural Concepts of Precedential Texts in Consciousness and Discourse, in Russian). Moscow: Academia.

Slyshkin, G. G. (2004). Lingvokul'turnyi kontsept kak sistemnoe obrazovanie (Linguocultural Concept as Systemic Formation, in Russian). Vestnik of Volgograd State University. Series "Linguistics and Intercultural Communication", 1, 29-34.

Stepanov, Y. S. (2001). Konstanty. Slovar' russkoi kul'tury (Constants. Dictionary of Russian Culture, in Russian). Moscow: Akademicheskiy Proekt.

Turner, M. (1994). Design for a Theory of Meaning. In Overton, W. \& Palermo, D. (Eds.), The Nature and Ontogenesis of Meaning (pp. 91-107). New Jersey: Lawrence Elbaum.

Vorkachev, S. G. (2002). Metodologicheskie osnovaniya lingvokontseptologii. Aspekty metakommunikativnoi deyatel'nosti: teoreticheskaya i prikladnaya lingvistika (Methodological Basis for Linguistis Concept Studies. The Aspects of Metacommunicative Activity: Theoterical and Applied Linguistics, in Russian). Inter-Institutional Collection of Scientific Works, 3, 79-95.

Vorkachev, S. G. (2004). Schaste kak lingvokul'- 
turnyi kontsept (Happiness as Linguocultural Concept, in Russian). Moscow: Gnozis.

Whipp, M. (2017). The Grace of Waiting: Learning Patience and Embracing its Gifts. London: Canterbury Press Norwich.

Xenophon (1993). Vospominaniya o Sokrate
(The Memorabilia of Socrates, in Russian). Moscow: Nauka.

Zusman, V. G. (2003). Kontsept v sisteme gumanitarnogo znaniya (Concept in the System of Arts, in Russian). Issues of Literature, 2, 3-29. 